\title{
Development Program Evaluation on Entrepreneurship Course in Vocational High School West Sumatra
}

\author{
Ambiyar $^{1(*)}$, Delima Yanti $^{1}$, Sari Azhariyah ${ }^{1}$ \\ ${ }^{1}$ Universitas Negeri Padang, Padang, Indonesia, \\ *Corresponding author.Email: ambiyar@ft.unp.ac.id
}

\begin{abstract}
Entrepreneurship learning is the main point to make Vocational High School graduates be able to create jobs in accordance with the demands of Indonesia's current development. This study aims to develop a program evaluation model for entrepreneurship learning in Vocational High Schools. This type of research is evaluation research. The research approach used is the Mixed Method. In this research the development model used is ADDIE (Analysis, Design, Development, Implementation and Evaluation). Based on the needs analysis, the CIPRO model (Context, Input, Process, Result, and Output) is obtained. This model is a combination of the CIPP and CIRO models. The CIPRO program evaluation model was developed based on a needs analysis by observing the implementation of entrepreneurial learning, interviews with teachers and students, and documentation relating to curriculum and learning tools. This model has been validated and can be used to evaluate entrepreneurship learning programs in Vocational High Schools.
\end{abstract}

\section{Keywords: Development, Evaluation, Entrepreneurship Learning, and Evaluation Model}

\section{INTRODUCTION}

Globalization era is a challenge and opportunity that can be utilized to be able to live in line and side with other countries. One side of globalization and industrialization opens up opportunities to accelerate the pace of development, but on the other hand brings the challenges of increasingly fierce competition. To be able to achieve better economic development of the country and be able to compete with other countries, superior quality human resources are needed. There is needed to create entrepreneurs, because they can grow the economy and creates jobs for unemployment (Murtini, 2016). One effort to improve the quality of human resources is through education. Vocational High School (SMK) is an educational institution that is expected to produce competent graduates in certain fields so that graduates have the provision of entrepreneurial skills. Entrepreneurship according to Timmon (Ganefri \& Hidayat, 2013) is a creative humanitarian act in building a value, pursue opportunities regardless of whether or not there are sources.

Vocational Schools are expected to be able to encourage the emergence of initiatives from students for entrepreneurship. According to Joko Sutrisno (2003: 3), "education with an entrepreneurial insight is education that applies principles and methodologies towards the formation of life skills in their students through a curriculum developed in schools". About $90 \%$ to $100 \%$ of vocational education students in Europe practice entrepreneurship programs, hence Entrepreneurship includes a national curriculum for vocational schools in most European countries. According to the European
Commission in 2009, personality is the spearhead of success in entrepreneurship so that it can foster creativity, a sense of initiative and courage in taking risks. This education is oriented to the formation of an entrepreneurial spirit, that is a spirit of courage and a willingness to face life's problems and life naturally, a creative student to find solutions and overcome these problems, an independent student and not dependent on others.

In order to providing students with life skills, vocational high schools must also shape their students' entrepreneurial attitudes and behaviors. Entrepreneurship education is given at school so students have live skills, the ability to adapt, and the ability to socialize as soft skills in the industry (Farida, 2018). Entrepreneurial attitudes and behavior are characterized by a strong will to achieve goals, confidence, honest, responsible, have physical and mental endurance, tenacity at work, creative thinking, innovative and constructive, and oriented to the future, and dare to take risks ( Kasmir, 2006: 27; Suryana, 2006: 3). In fact, vocational high schools in general only provide entrepreneurial skills that lead to work skills, the skills that shape students into workers or laborers without instilling an entrepreneurial spirit in students.

If a country wants to prosper, then they must have entrepreneurs of at least $2 \%$ of the population, Hence, based on data from the Indonesian Ministry of National Education in 2007 of 75.3 million young people in Indonesia, $6.6 \%$ were tertiary graduates, of which $82 \%$ were workers, while only $18 \%$ worked alone or became entrepreneurs. Whereas $85 \%$ of SMK graduates choose to become workers, $8 \%$ of SMK graduates choose to continue their studies in vocational fields, $5.5 \%$ of SMK 
graduates choose to become entrepreneurs and $1.5 \%$ do not have plans after graduating from SMK (Tyagita \& Padmini, 2015). One of the ways in which talented entrepreneurs are created is through entrepreneurship programs. According to Soni Heru Priyanto (2009, 76) entrepreneurship education needs to be directed at developing competencies that can be used in work and life. Therefore entrepreneurship education has objectives namely motivational education, knowledge education, skills education and skills development.

Learning entrepreneurship in vocational schools in general, is only done by giving the concept of entrepreneurship in the classroom. Beside, Vocational High Schools continue to provide opportunities for students to undergo industrial work practices as a form of providing entrepreneurial readiness for students. Entrepreneurship learning oriented to the formation of life skills must pay attention to four principles, namely 1) learning to know entrepreneurship; 2) learning to do entrepreneurial activities; 3) learning to practice entrepreneurial activities; 4) learning together with others in social interaction of entrepreneurship. These four principles have the same purpose with the four learning pillars by Hidayanto (Anwar, 2004: 5), namely 1) knowledg; 2) skills; 3) independence and; 4) the ability to adapt and work together. This study aims to produce a valid learning program evaluation model.

\section{METHOD}

This type of research is a program evaluation study (Evaluation Research). This evaluation research aims to evaluate a program, evaluate the implementation of an object and with the aim of improvement. According to Sugiyono (2012: 407) research and development are research methods used to produce certain products, and test the effectiveness of these products. Nana Syaodih Sukmadinata (2006: 169) defines research and development as a research approach to produce new products or improve existing products. Development research is a method for producing certain products or perfecting existing products and testing the effectiveness of those products.

The research approach used is a Combined Method (Mixed Method). According to Sugiyono (2013: 404) mixed method research is "Is an approach to inquiry that combines or is associated both qualitative quantitative forms of research. It involves philosophical assumptions of the use of quantitative and qualitative approaches, and the mixing of both approaches approached in a study. Combined research methods are approaches in research that combine or link between quantitative and qualitative research methods.

The development design that will be used in this research is ADDIE. Following is an explanation of the ADDIE development stage that researchers will undertake: 1) Analyze phase is the stage where the researcher analyzes the need for the development of teaching materials and analyzes the feasibility and development requirements. Stages of analysis by the author include three things, namely needs analysis, curriculum analysis, and student character analysis. In the program evaluation analysis is done by taking into account the characteristics of the curriculum being used in a school. This is done so that the development carried out can be in accordance with the demands of the applicable curriculum; 2) Designing stage, researchers develop instruments that will be used to assess the entrepreneurship learning program developed. The instruments were prepared with regard to aspects of entrepreneurship learning programs; 3) Developing a Model (Development) stage is the stage of product realization. At this stage the development of learning program evaluation is carried out in accordance with the design. After that, the evaluation of the entrepreneurship learning program will be validated by expert lecturers and teachers. In the validation process, the validator uses instruments that were prepared in the previous stage; 4) Implement (Implementation) stage is implementation. Implementation is limited to schools designated as research sites; 5) Evaluating the Results of the Trial (Evaluation) stage, the researcher makes a final revision of the evaluation of the program developed based on the input obtained from the response questionnaire or field notes on the observation sheet. It is intended that the evaluation of the program developed is truly appropriate and can be used by the wider school.

The instruments used for collection in the first year were observation sheets, interview guidelines, and documentation. The data obtained is used to develop a program evaluation model. Then the questionnaire is used (questionnaire) to collect data to tests validity.

\section{RESULTS AND DISCUSSION}

The results of this study develop a model that can be used to evaluate entrepreneurial learning programs. The program evaluation model developed was based on needs analysis by observing the implementation of entrepreneurship learning, interviews with teachers and students, and documentation relating to curriculum, learning tools and evaluation instruments. Observations on Vocational Schools which are the target of research on entrepreneurship subjects originating from students are difficulties in understanding entrepreneurial learning, because entrepreneurial learning is required in understanding various analyzes in entrepreneurship and producing a product. So the students have not been able to have attitudes, character, entrepreneurial behavior and life skills. This causes there are still graduates of vocational students who still do not get a job because they are unable to meet the demands of competence by the industry and are unable to open their own jobs. Student responses to entrepreneurship are still lacking, so students are not actively participating in learning entrepreneurship.

The problem faced by teachers is that in the entrepreneurial learning process is the limited number of practical facilities that can be used to produce a product, so students take turns in using the means of practice. Therefore, the learning process that occurs is that the teacher explains more and demonstrates the lesson without 
involving all students to practice. The way of presenting the material is less interesting because the teacher's ability to convey entrepreneurial learning methods is not right so students become less motivated to take lessons. This shows that the learning process that has taken place so far is not a student centered learning process. Hence, it will have an impact on low student learning outcomes in entrepreneurial learning. Besides the lack of involvement of the industrial world to participate in creating students who have a strong entrepreneurial spirit.

Interview activities were conducted with entrepreneurship subject teachers, related to the assessment techniques used. Interviews with entrepreneurship subject teachers in several places such as the Business and Management Vocational School, Technology Vocational School, and Tourism and Hospitality Vocational School, the results were obtained that the teachers used the assessment with tests in the form of essay and objective multiple choice and assessment of student performance. The assessment of learning outcomes for entrepreneurship subjects carried out by the teacher is more evaluating on the cognitive and psychomotor aspects, not touching the affective aspects. Therefore the assessment design developed for entrepreneurship subjects refers to the three domains, namely cognitive, affective, and psychomotor.

The curriculum used in schools in West Sumatra targeted in this study is to use the 2013 curriculum. Then each school has a syllabus format and a lesson plan (RPP) in accordance with the curriculum used. In the 2013 curriculum there are core competencies (core competencies 1 to 4 ) and basic competencies. In this study the students observed in Entrepreneurship learning were class XI students in several different schools. The assessment system used by teachers to assess student learning outcomes in each school is different. Some apply the tests and performance that have been given by students. Some apply assessments based on programs that have been made by students and tests. Regarding the test, there are those applying the multiple choice objective test and essay test. In the development phase, the curriculum will be used in the 2013 curriculum. Referring to the strengths and weaknesses of each test, both the multiple choice objective test and the essay test, the test that will be used to assess the learning outcomes of entrepreneurship subjects in the cognitive realm is used a combination of multiple choice test and essay test.

Based on observations, interviews, curriculum analysis, and student analysis it can be concluded that in the entrepreneurship learning process at Vocational School West Sumatra required assessment instruments that can be used by teachers and students to improve student learning outcomes so as to achieve the KKM value specified by the school and the program evaluation model to see the achievement of entrepreneurship programs in entrepreneurship lessons in vocational secondary schools.

Some program evaluation models that serve as a reference in this development include CIPP (Context, Input, Process, and Product) from Stufflebeam and CIRO (Context, Input, Result, and Outcome). Based on the needs analysis, an evaluation model of the CIPRO program is obtained with a combination of the CIPP (Context, Input, Process, and Product) and CIRO (Context, Input, Result, and Outcome) models. The model developed was tested for validity. By analyzing the results of expert judgment using Aiken's V validity coefficient the product validity results are obtained. According to (Azwar, 2012) "Aiken has formulated the Aiken $\mathrm{V}$ formula to calculate the Content Validity Coefficient which is based on an expert panel's evaluation of $n$ people on an item regarding the extent to which the item represents the construct being measured. Assessment is done by giving a number between 1 (very unrepresentative or highly irrelevant) to 4 (highly representative or highly relevant). Following is the formula from Aiken's V (Azwar, 2012: 113),

$\mathrm{V}=\Sigma \mathrm{S} /[\mathrm{n}(\mathrm{c}-1)]$

With the statement $\mathrm{n}$ is the number of the panel of judges (expert), lo are the Lowest Validity Rating (in this case $=1$ ), $\mathrm{c}$ is the Highest Validity Rating Score (in this case $=5$ ), $r$ is the Number Given by an Appraiser, and $s$ is $\mathrm{r}$ - lo. Because the range of the number $\mathrm{V}$ that can be obtained is between 0 to 1.00 , the number 0.600 can be interpreted as a high enough coefficient for the item. Validation test by validator on the CIPRO evaluation model can be seen in Table 1 .

Table 1. Summary of Validity Results for the CIPRO Model

\begin{tabular}{lccc}
\hline Aspect & $\begin{array}{c}\text { Score } \\
\text { Aiken }\end{array}$ & \multicolumn{2}{c}{$\begin{array}{c}\text { Informati } \\
\text { on }\end{array}$} \\
\hline omponent Aspects & 0.869 & & Valid \\
\hline Language Aspects & 0.883 & & Valid \\
\hline
\end{tabular}

Based on table 1, the results of the validity test of the CIPRO model of 3 validators stated that from all aspects of the assessment have valid criteria. Asul Wiyanto and Mustakim (2012) stated that good data is data obtained from data collection instruments that are also valid and reliable. From the results of the validity test it can be seen that the level of validation of the CIPRO model is in the range 0.869-0.883. Thus it can be concluded that the CIPRO program evaluation model is valid and can be used to measure entrepreneurship programs in Vocational High Schools. The CIPRO model can be done by looking at the context, input, process, results, and impact of entrepreneurship learning in SMK.

\section{CONCLUSIONS}

The development of entrepreneurship program evaluation is expected to be able to produce a program evaluation model that can be applied to entrepreneurship lessons in West Sumatra Vocational High Schools (SMK). The problem for implementation of affective assessment in schools on entrepreneurship learning is the difficulty of teachers developing the entrepreneurship assessment instrument. The design of instruments for assessment in entrepreneurship learning can be developed with four methods, namely observation, interview, documentation and questioner. The development of the Entrepreneurship 
assessment instrument needs to consider validity, from the validity test conducted by 3 experts it was found that the CIPRO model is valid and can be used to evaluate entrepreneurship lessons. By looking at the context, inputs, processes, results, and outcomes of entrepreneurship lessons in Vocational High Schools.

\section{REFERENCES}

[1] Anwar. (2006). Pendidikan Kecakapan Hidup (Life Skills Education) Konsep dan Aplikasi. Bandung: Alfabeta.

[2] Asuk Wiyanto dan Mustakim. (2012). Panduan Karya Tulis Guru. Yogyakarta: Pustaka Grhatama (Anggota Ikapi)

[3] Azwar, S. (2012). Reliabiltas dan Validitas. Yogyakarta: Pustaka Pelajar.

[4] Farida, R. (2018). Realiasasi Spirit Entreprenuership melalui Website Berbasis ECommerce di kalangan Mahasiswa (Studi Pada Mahasiswa Jurusan Syariah dan Ekonomi Islam IAIN Kudus). Jurnal Bisnis dan Manajemen Islam, 6(2): 127-140

[5] Ganefri, \& Hidayat, H. (2013). Rahasia Kewirausahaan. Padang: Alfabeta

[6] Joko Sutrisno. (2003). Pengembangan Pendidikan Wawasan Wirausaha Sejak Anak Usia Dini.

[7] Kasmir. (2006). Kewirausahaan. Jakarta: Raja Grafindo.

[8] Murtini, W. (2016). Implementasi Model "Gepprak" Dalam Pembelajaran Kewirausahaan Untuk Meningkatkan Niat Berwirausaha Di Sekolah Menengah Kejuruan. Jurnal Pendidikan Vokasi, 6(3): 335-345.

[9] Sony Heru Priyanto. (2009). Mengembangkan Pendidikan Kewirausahaan di Masyarakat.

[10] Sugiyono. (2012). Metode Penelitian Kuantitatif Kualitatif dan $R \& D$. Bandung: Alfabeta.

[11] Sugiyono. (2013). Metode Penelitian KOMBINASI (Mixed Methods). Bandung: ALFABETA.

[12]Sukmadinata, Nana Syaodih, (2006). Metode Penelitian Pendidikan. Bandung: PT. Remaja Rosdakarya.

[13] Suryana. (2006). Kewirausahaan. Jakarta: Salemba Empat. 